\title{
Hreyfing íslenskra grunnskólanema
}

\section{Pórdís Gísladóttir, Rúnar Vilhjálmsson og Vaka Rögnvaldsdóttir \\ Abstract $\quad$ Um höfunda About the authors $>$ Heimildir}

Gildi hreyfingar fyrir líkamlega og andlega heilsu er vel pekkt. Prátt fyrir pá vitneskju dregur úr hreyfingu frá barnsaldri til unglingsára og almennt er hreyfingu ábótavant. Pví er mikilvægt að kanna hreyfingu barna og unglinga með pað fyrir augum að efla hana og sporna við hreyfingarleysi.

Markmið pessarar rannsóknar var að kanna umfang líkamlegrar hreyfingar íslenskra grunnskólanema í 6., 8. og 10. bekk og tengsl hennar við kyn, aldur, uppruna, fjölskyldugerð, efnahag og búsetu. Sérstaklega var athugað hve hátt hlutfall nemendanna næði ráðlagðri 60 mínútna hreyfingu daglega.

Unnið var úr gögnum úr landskönnuninni Heilsa og lífskjör skólanema (Health Behavior in School-aged Children - HBSC) sem fór fram árið 2018. Alls tóku 6.102 nemendur í 6., 8. og 10. bekk úr 86 grunnskólum á landinu pátt í rannsókninni. Spurningalistar voru lagðir fyrir nemendur og meðal annars var spurt um fjölda daga á viku sem pátttakendur stunduðu „líkamlega hreyfingu samanlagt í 60 mínútur eða meira á dag“. Pá var einnig spurt um kyn og bekkjardeild, efnahagslega stöðu fjölskyldu, uppruna foreldra, fjölskyldugerð og búsetu.

Að meðaltali stundaði nemendahópurinn líkamlega hreyfingu í 4,5 daga í viku. Einungis $21 \%$ nemenda náði viðmiði um ráðlagða daglega hreyfingu. Fleiri piltar en stúlkur náðu viðmiðum um hreyfingu og fleiri nemendur í 6 . bekk samanborið við eldri nemendur. Nemendur sem tilheyrðu fjölskyldum með lakari efnahag, bjuggu ekki með báðum kynforeldrum, eða áttu foreldra af erlendum uppruna, náðu síður viðmiðum um ráðlagða hreyfingu. Ekki var munur á hreyfingu grunnskólanema eftir búsetu peirra.

Vinna parf að hreyfieflingu grunnskólanema með fræðslu um gildi hennar, daglegum hreyfistundum á skólatíma og markvissum ípróttatímum. Jafna parf pátttöku barna í ípróttum utan skólans með aðkomu sveitarfélaganna. Fjölga parf möguleikum til hreyfingar fyrir alla utan húss og innan í sveitarfélögum landsins.

Efnisorð: Hreyfing, ípróttapátttaka, unglingar, efnahagsleg staða, fjölskyldugerð, búseta

\section{Inngangur}

Ávinningur líkamlegrar hreyfingar fyrir andlega (Bell o.fl., 2019) og líkamlega (Myers o.fl., 2019) heilsu er vel pekktur. Í nútímasamfélagi er líkamleg hreyfing mikilvæg í forvarnar- og lýðheilsustarfi. Fjölmargar rannsóknir hafa sýnt fram á gildi líkamlegrar hreyfingar fyrir heilsu, líðan og proska ungmenna (Aarnio o.fl., 2002; Bedard o.fl., 2020). Líkamleg hreyfing á unglingsaldri spáir fyrir um líkamlega hreyfingu síðar á ævinni (Belanger o.fl., 2015; Telama o.fl., 2005) og minnkar líkur á áunnum lífsstílssjúkdómum (Hallal o.fl., 2006). 
Ráðleggingar Albjóða heilbrigðismálastofnunarinnar (WHO) um hreyfingu miða við að börn og unglingar stundi hreyfingu af miðlungs eða mikilli ákefð í minnst 60 mínútur daglega (Lýðheilsustöð, 2008; World Health Organization, 2010) og par af ætti að stunda krefjandi æfingar sem styrkja bein og vöðvavef minnst prisvar í viku (Lipnowski o.fl., 2012; World Health Organization, 2020). Prátt fyrir aukna vitund um ávinning af líkamlegri hreyfingu, uppfyllir mikil fjöldi barna og unglinga á skólaaldri ekki viðmið um ráðlagða lágmarks daglega hreyfingu (Clemens og Lincoln, 2018; Currie o.fl., 2012). Ráðleggingar og mat á reglulegri hreyfingu barna og unglinga hafa gjarnan verið áætluð út frá spurningalistum um hreyfingu eða kyrrsetu (Andersen o.fl., 1998) og hreyfing skoðuð í tengslum við heilsufarspætti eins og líkamshreysti (Aaron o.fl., 1993). Ráðleggingar WHO um líkamlega hreyfingu hafa verið settar fram til pess að stuðla að líkamshreysti, afkastagetu lungna, hjarta- og æðakerfis, vöðva- og beinvefs, og til að draga úr efnaskiptasjúkdómum, kvíða og punglyndi (World Health Organization, 2010). Til viðbótar við ráðleggingar um hreyfingu er börnum og ungmennum ráðlagt að takmarka kyrrsetustundir sínar, pá sérstaklega skjátíma sinn utan skóla- og vinnutíma (World Health Organization, 2020). Aukin kyrrseta meðal barna og ungmenna hefur verið tengd við slakari lífsgæði, minna sjálfstraust, aukinn kvíða og punglyndi (Saunders og Vallance, 2017). Auk pess hafa fundist tengsl milli kyrrsetu og offitu barna en talið er að eitt af hverjum sex börnum glími við of pyngd eða offitu (OECD, 2017), sem eru áhættupættir fyrir hjarta- og æðasjúkdóma (Freedman o.fl., 2007), efnaskiptasjúkdóma og krabbamein (Biro og Wien, 2010). Einnig er talið að ofpyngd og offita geti haft í för með sér félagslega einangrun eða útilokun. Pá hafa fundist jákvæð tengsl milli hreyfingar og vitsmunalegra pátta (Fedewa og Ahn, 2011) og námsárangurs meðal barna og unglinga (Elvar S. Sævarsson o.fl., 2017; Fox o.fl., 2010; Trudeau og Shephard, 2009).

Pátttaka í ípróttum er meðal annars talin til marks um líkamlega hreyfingu einstaklinga (Elvar $S$. Sævarsson o.fl., 2021; Hebert o.fl., 2015; Marques o.fl., 2016; Vaka Rögnvaldsdóttir o.fl., 2018). Ípróttir eru aðgengilegar flestum börnum og unglingum á Vesturlöndum og talið að um tveir priðju evrópskra barna taki pátt í einhvers konar ípróttastarfi (Kokko o.fl., 2019). Hlutfallsleg ípróttapátttaka meðal 14 og 15 ára unglinga á Íslandi jókst úr 40\% árið 1992 í 60\% árið 2014 (Viðar Halldórsson, 2014). Î́ pýskri rannsókn á börnum og unglingum á aldrinum 6-17 ára kom í ljós að pá daga sem pau sóttu skólaípróttir og/eða skipulagðar ípróttaæfingar voru pau líklegri til að stunda hreyfingu af ráðlagðri ákefð (Sprengeler o.fl., 2019). Daglegt míluhlaup (e. the daily mile) er vinsælt hreyfiverkefni í grunnskólum í Evrópu. Nýleg rannsókn meðal 9-11 ára barna í Bretlandi sýndi að daglegt míluhlaup eykur líkur á að nemendur nái ráðlagðri daglegri hreyfingu (Hatch o.fl., 2021). Pessar niðurstöður benda til pess að pví meiri tíma sem börn og unglingar fá í skólaípróttum, annarri hreyfingu á skólatíma og á ípróttaæfingum aukast líkur á ákafri hreyfingu hjá peim. Í rannsóknum á börnum og unglingum sýna niðurstöður að piltar hreyfa sig meira en stúlkur (Babey o.fl., 2018; Kristján Pór Magnússon o.fl., 2011; Pulido Sanchez og Iglesias Gallego, 2021; Riddoch o.fl., 2004; Sallis, 1993; Vaka Rögnvaldsdóttir o.fl., 2018; Van Hecke o.fl., 2016). Pá hefur hreyfing stúlkna einnig mælst af minni ákefð en hreyfing drengja (Hatch o.fl., 2021; Inchley o.fl., 2005). Rannsóknir á yngri börnum sýna síður kynjamun á hreyfingu (Babey o.fl., 2018; Manios o.fl., 1999). Heildarhreyfing barna minnkar með hækkandi aldri (Sallis, 1993) og pá sérstaklega meðal stúlkna (Aaron o.fl., 1993). Talið er að hreyfing barna og unglinga (7-19 ára) minnki um 7\% á ári, hjá stúlkum dregur mest úr hreyfingu á aldursbilinu 9-12 ára en hjá drengjum á aldursbilinu 13-16 ára (Manios o.fl., 1999). Íslensk rannsókn skoðaði breytingar á hreyfingu 15-23 ára ungmenna. Á pessu 8 ára aldursbili minnkaði hreyfing stúlknanna um 50\% eða að meðaltali um 6\% á ári og hreyfing drengja minnkaði um 60\% eða um 7\% á ári (Guðrún Sunna Gestsdóttir, 2016).

Ólík félags- og efnahagsstaða fjölskyldna er pekkt spábreyta fyrir almennt heilsufar (Adler o.fl., 1994; Elgar o.fl., 2015). Sem dæmi má nefna að börn og unglingar sem búa á betur stæðum heimilum eru líklegri til pess að hreyfa sig meira, borða hollari mat og búa yfir meiri lífsánægju og vellíðan en pau sem búa við lakari efnahagsstöðu (Chzhen o.fl., 2016). Pá sýna rannsóknir að peir unglingar sem stunda ípróttir með ípróttafélagi eru líklegri að koma frá heimilum sem eru fjárhagslega betur stæð (Amalía Björnsdóttir o.fl., 2009; Dollman og Lewis, 2010; Walters o.fl., 2009). 
Fjölskyldugerð getur einnig haft áhrif á heilsu og hreyfingu barna og unglinga en skilgreining á fjölskyldugerðum milli rannsókna og tengslum við heilsufarspætti er pó með ólíkum hætti. Peir sem búa hjá einstæðu foreldri eða í annarri fjölskyldugerð en hjá báðum kynforeldrum, virðast hreyfa sig í færri daga á viku og taka síður pátt í skipulögðu ípróttastarfi hjá ípróttafélagi en unglingar sem búa hjá báðum líffræðilegum foreldrum (Langoy o.fl., 2019; Viðar Halldórsson, 2014).

Nokkuð hefur verið birt af rannsóknum varðandi búsetu og hreyfingu unglinga en niðurstöður eru ekki samhljóma. Auk pess er skilgreining á dreifbýli og péttbýli með ólíkum hætti í erlendum rannsóknum. Sumar rannsóknir hafa sýnt að unglingar sem búsettir eru í dreifbýli hreyfi sig minna en unglingar í péttbýli (Felton o.fl., 1998; Guðrún Kristjánsdóttir og Rúnar Vilhjálmsson, 2001), en aðrar rannsóknir hafa komist að hinu gagnstæða (Liu o.fl., 2008).

Hreyfing og ípróttapátttaka barna og unglinga af erlendum uppruna getur haft jákvæð áhrif á lífsgæði peirra og félagslega virkni í samfélaginu par sem pátttaka í ípróttum með ípróttafélagi er samofin félagslegum tengslum og samskiptum (Toselli og Belcastro, 2017). Erlendar rannsóknir sýna að innflytjendur taka síður pátt í hreyfingu (Pedersen og Seidman, 2005; Singh o.fl., 2008; Toselli og Belcastro, 2017; Zaccagni o.fl., 2017) og ípróttum utan skóla en innfæddir (Zaccagni o.fl., 2017).

Líkamleg hreyfing hefur jákvæð tengsl við aðra heilsutengda hegðun svo sem svefn, mataræði og reykleysi (Lang o.fl., 2016; Lipsky o.fl., 2017; Pórólfur Pórlindsson o.fl., 1990). Prátt fyrir ávinninginn af líkamlegri hreyfingu sýna rannsóknir umtalsverðan samdrátt í tíma og fjölda daga sem varið er í líkamlega hreyfingu frá barnæsku til unglingsára og að hreyfingu ungs fólks sé almennt ábótavant, pótt vandinn sé mismikill eftir aldurshópum (Farooq o.fl., 2020; Guðrún Kristjánsdóttir og Rúnar Vilhjálmsson, 2001). Jafnframt benda rannsóknir til pess að líkamleg hreyfing á unglingsaldri spái að nokkru leyti fyrir um líkamlega hreyfingu á fullorðinsaldri (Belanger o.fl., 2015; Hallal o.fl., 2006; Telama o.fl., 2005). Pví er mikilvægt að kanna hreyfingu meðal barna og unglinga með pað fyrir augum að efla hana og sporna við hreyfingarleysi.

Markmið pessarar rannsóknar var að kanna umfang líkamlegrar hreyfingar íslenskra grunnskólanema í 6., 8. og 10. bekk og tengsl hennar við kyn, aldur, uppruna, fjölskyldugerð, efnahag og búsetu. Sérstaklega var athugað hve hátt hlutfall nemendanna næði ráðlagðri 60 mínútna hreyfingu daglega.

\section{Efniviður og aðferðir}

Unnið var úr gögnum úr landskönnuninni Heilsa og lífskjör skólanema (Health Behavior in School-aged Children - HBSC) sem tengist fjölpjóðlegu samstarfsverkefni í um 40 löndum með stuðningi WHO. Landskönnunin fór fram árið 2018 par öllum grunnskólum landsins var boðin pátttaka fyrir nemendur í 6., 8. og 10. bekk (12, 14 og 16 ára). Nafnlausir staðlaðir spurningalistar um aðstæður, lifnaðarhætti og heilsufar voru lagðir fyrir nemendurna í skólastofu á skólatíma. Á fyrstu síðu spurningalistans var nemendum meðal annars heitið nafnleynd og bent á að peim væri ekki skylt að svara spurningalistanum í heild eða einstökum spurningum (Einar B. Porsteinsson og Ársæll Arnarsson, 2018). Âđur en gagnasöfnun hófst var spurningalistinn ásamt rannsóknaráætlun sendur til Persónuverndar og Vísindasiðanefndar Háskóla Íslands. Engar athugasemdir voru gerðar við fyrirhugaða framkvæmd, enda er um ópersónugreinanleg gögn að ræða. Landskönnunin fékk einnig leyfi til fyrirlagnar hjá skólastjórnendum í pátttökuskólunum. Alls tóku 6.102 skólanemar pátt í landskönnuninni í 86 grunnskólum (af 169). Heimtur (svarhlutfall) í pátttökuskólunum voru yfir 80\% en fjöldi svarenda var 55,5\% af heildarfjölda nemenda í grunnskólum landsins. Aldurs- og kynjasamsetning svarendahópsins samsvaraði vel aldurs- og kynjasamsetningu íslenskra grunnskólanema í 6., 8. og 10. bekk. Langflestir nemendur svöruðu öllum spurningum, en svarbrottfall í einstökum spurningum var frá $0-1,5 \%$. Í rannsókninni er unnið með gild svör í hverri spurningu. 


\section{Umfang líkamlegrar hreyfingar}

Með hliðsjón af ráðleggingum WHO var meðal annars spurt um fjölda daga á viku sem pátttakendur stunduðu „líkamlega hreyfingu samanlagt í 60 mínútur eða meira á dag“. Til útskýringar var pátttakendum sagt að líkamleg hreyfing gæti meðal annars átt sér stað í ípróttum, í skólanum, í leik með vinum, eða á leiðinni í og úr skóla. Dæmi um líkamlega hreyfingu væru hlaup, röskleg ganga, línuskautar, hjólreiðar, dans, hjólabretti, sund, fótbolti, körfubolti, handbolti, skíði og snjóbretti. WHO ráðleggur að börn og unglingar á aldrinum 5-17 ára stundi slíka hreyfingu daglega. Tvær breytur rannsóknarinnar vörðuðu hreyfingu. Önnur greindi milli peirra sem stunduðu ráðlagða hreyfingu (í 60 mínútur nær daglega) og hinna sem ekki gerðu pað. Hin breytan skráði hve marga daga í viku pátttakendur stunduðu 60 mínútna daglega hreyfingu.

\section{Lýðfræðileg staða, efnahagur fjölskyldu, uppruni, fjölskyldugerð og búseta}

Nemendurnir voru spurðir um kynferði, bekkjardeild (6., 8. eða 10. bekkur), og uppruna foreldra eftir fæðingarlandi og greint á milli pess hvort báðir foreldrar, annað foreldrið, eða hvorugt foreldrið væri fætt erlendis. Einnig var spurt um fjölskyldugerð og greint á milli peirra sem bjuggu með báðum lífforeldrum, með einstæðu foreldri, í stjúpfjölskyldu, eða í öðru fjölskyldufyrirkomulagi. Pá var efnahagur fjölskyldunnar metinn með svonefndum FAS- kvarða (e. Family Affluence Scale) (Torsheim o.fl., 2016). Efnahagskvarðinn (FAS-kvarði) var byggður á spurningum um hvort fjölskyldan ætti bíl, hvort nemandinn hefði eigið svefnherbergi, hve margar tölvur fjölskyldan ætti, hve mörg baðherbergi væru á heimilinu, hvort upppvottavél væri á heimilinu, og hve oft fjölskyldan hefði farið til útlanda sl. 12 mánuði. Stig fyrir hverja spurningu voru lögð saman í 0-13 stiga efnahagskvarða. Við tölfræðilega úrvinnslu voru stigin flokkuð og greint á milli lakrar (0-7 stig), miðlungs (8-10 stig) og hárrar (11-13 stig) efnahagsstöðu. Loks var búseta metin út frá póstnúmeri og greint á milli peirra sem bjuggu á höfuðborgarsvæðinu eða landsbyggðinni.

\section{Tölfræðileg úrvinnsla}

Munur á hlutfallstíðni peirra sem náðu viðmiðum um ráðlagða hreyfingu var metinn eftir hópum nemenda (kyni, bekkjardeild, efnahag fjölskyldu, pjóðernisuppruna, fjölskyldugerð og búsetu), marktekt metin með kí-kvaðrat marktektarprófi og fylgni metin með Phi og Cramér's $V$ fylgnistuðlum. Meðaltalsmunur á dagafjölda hreyfingar milli hópa var metinn með t-marktektarprófi pegar hópar eru tveir, en F-marktektarprófi pegar hópar eru fleiri og fylgni metin með Eta-fylgnistuðli. Marktektarmörk miðuðust við $\mathrm{p}<0,05$. Við innbyrðis samanburð milli hópa nemenda innan einstakra bakgrunnsbreyta voru marktektarmörk leiðrétt með Bonferroni-leiðréttingu til að draga úr líkum á að marktekt ákvarðaðist fyrir tilviljun.

\section{Niðurstöður}

Að meðaltali stundaði nemendahópurinn líkamlega hreyfingu í 4,5 daga í viku og hlutfall nemenda sem náðu viðmiði um ráðlagða (daglega) hreyfingu var einungis 21,0\%. Engu að síður náðu $83 \%$ nemendanna að hreyfa sig að minnsta kosti prisvar í viku (Tafla 1). Mynd 1 sýnir skiptingu ráðlagðrar hreyfingar eftir bekkjardeild og kyni. Myndin sýnir að hlutfall nemenda sem náði ráðleggingum um hreyfingu var nokkuð breytilegt eftir aldri hjá piltum og stúlkum. Pannig náðu piltar í 6 . bekk oftar ráðlagðri hreyfingu en piltar í 10. bekk $(\mathrm{p}<0,05)$ og stúlkur í 6. bekk náðu marktækt oftar rádlagðri hreyfingu en stúlkur í 8 . bekk $(\mathrm{p}<0,01)$. 
Tafla 1. Samsetning pátttakenda eftir bakgrunni og hreyfingu.

\begin{tabular}{lcc} 
& $\%$ & Fjöldi \\
\hline $\begin{array}{c}\text { Kynferði } \\
\text { Piltur }\end{array}$ & 49,2 & $2955 / 6008$ \\
Stúlka & 50,8 & $3053 / 6008$ \\
Bekkur & & \\
6. bekkur & 31,0 & $1889 / 6102$ \\
8. bekkur & 36,0 & $2197 / 6102$ \\
10. bekkur & 33,0 & $2016 / 6102$
\end{tabular}

Uppruni foreldra

Báðir innlendir

82,4

$4958 / 6018$

Annað erlent

11,1

$668 / 6018$

Bádir erlendir

6,5

$392 / 6018$

\section{Fjölskyldugerð}

Báðir kynforeldrar

72,5

$4384 / 6047$

Einstætt foreldri

11,4

689/6047

Stjúpfjölskylda

6,6

$398 / 6047$

Önnur fjölskyldugerð

9,5

$576 / 6047$

Efnahagur fjölskyldu

$\begin{array}{llr}\text { Lakur } & 16,0 & 956 / 5977 \\ \text { Miðlungs } & 59,7 & 3566 / 5977 \\ \text { Hár } & 24,3 & 1455 / 5977\end{array}$

Búseta

Höfuðborgarsvæði

58,8

$3591 / 6102$

Landsbyggð

41,2

2511/6102

Dagafjöldi hreyfingar

0 dagar í viku

$4,7 \quad 285 / 6072$

1 dagur í viku

4,4

268/6072

2 dagar í viku

7,9

479/6072

3 dagar í viku

11,8

$714 / 6072$

4 dagar í viku

16,3

$987 / 6072$

5 dagar í viku

18,2

$1108 / 6072$

6 dagar í viku

15,8

957/6072

7 dagar í viku

21,0

1274/6072 


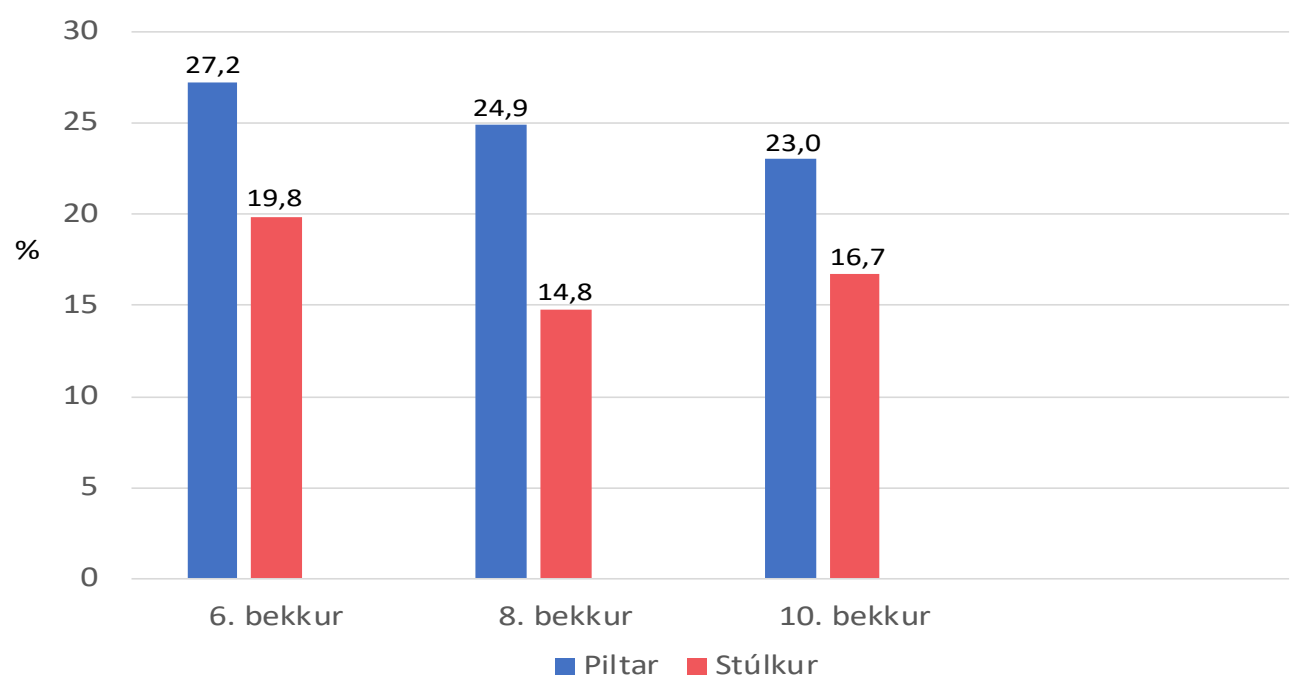

Mynd 1. Hlutfall grunnskólanema sem uppfylla viðmið um 60 mínútna daglega hreyfingu skipt upp eftir bekkjardeild og kyni.

Marktækur munur var á ráðlagðri hreyfingu og dagafjölda hreyfingar eftir hópum, eins og sjá má í Töflu 2. Vinstri hluti töflunnar sýnir hlutföll nemenda sem náðu ráðlagðri (daglegri) líkamlegri hreyfingu. Piltar náðu frekar ráðlagðri hreyfingu en stúlkur ( $<<0,001)$. Pá var munur á ráðlagðri hreyfingu eftir bekkjardeild $(\mathrm{p}<0,01)$. Nánari greining á bekkjamuninum sýndi að nemendur í 6 . bekk náðu frekar ráðlagðri hreyfingu en nemendur í 8 . bekk $(\mathrm{p}<0,01)$ og 10. bekk $(\mathrm{p}<0,05)$. Pjóðernisuppruni foreldra tengdist einnig ráðlagðri hreyfingu $(\mathrm{p}<0,05)$. Nánar kom í ljós að nemendur sem áttu báða foreldra af innlendum uppruna náðu oftar ráðlagðri hreyfingu en peir sem áttu foreldri af erlendum uppruna $(\mathrm{p}<0,05)$. Einnig var munur á ráðlagðri hreyfingu eftir fjölskyldugerð $(\mathrm{p}<0,001)$. Sá munur fólst í að nemendur sem bjuggu með báðum kynforeldrum náðu oftar ráðlagðri hreyfingu en nemendur sem bjuggu með einstæðu foreldri ( $\mathrm{p}<0,001)$ eða í stjúpfjölskyldu $(\mathrm{p}<0,05)$. Pá var munur á ráðlagðri hreyfingu eftir efnahag fjölskyldunnar $(\mathrm{p}<0,001)$. Nánar kom í ljós að mun algengara var að nemendur sem komu úr fjölskyldum með háa efnahagsstöðu næðu ráðlagðri hreyfingu en nemendur sem komu úr fjölskyldum með miðlungs efnahagsstöðu $(p<0,01)$ eða laka efnahagsstöðu $(p<0,001)$. Einnig var algengara að nemendur með miðlungs efnahagsstöðu næðu ráðlagðri hreyfingu en nemendur með laka efnahagsstöðu. Ekki var marktækur munur á ráðlagðri hreyfingu eftir búsetu. Fylgnistuðlarnir Phi og Cramér’s V sýna að ráðlögð hreyfing var í sterkustu sambandi við efnahag foreldra, par á eftir kom kyn og svo fjölskyldugerð.

Hægri hluti Töflu 2 sýnir vikudaga í líkamlegri hreyfingu eftir hópum. Fleiri daga í líkamlegri hreyfingu var að finna meðal pilta en stúlkna $(\mathrm{p}<0,001)$. Munur var á dagafjölda í hreyfingu milli bekkjardeilda $(\mathrm{p}<0,001)$. Nánari greining sýndi að nemendur í 6 . bekk hreyfðu sig fleiri daga en nemendur í 8. bekk $(p<0,001)$ og nemendur í 10. bekk $(p<0,001)$. Nemendur í 8. bekk hreyfðu sig einnig fleiri daga en nemendur í 10. bekk $(\mathrm{p}<0,001)$. Pá var munur á dagafjölda hreyfingar eftir pjóðernisuppruna nemenda. Nánari skoðun sýndi að nemendur sem áttu báða foreldra af innlendum uppruna hreyfðu sig fleiri daga en peir sem áttu annað eða báða foreldra af erlendum uppruna $(\mathrm{p}<0,001)$. Nemendur með annað foreldrið af erlendum uppruna hreyfðu sig einnig fleiri daga en nemendur með báða foreldra af erlendum uppruna $(\mathrm{p}<0,01)$. Loks var munur á dagafjölda hreyfingar eftir fjölskyldugerð. Nánar kom í ljós að nemendur sem bjuggu með báðum kynforeldrum stunduðu líkamlega hreyfingu í fleiri daga en nemendur einstæðra foreldra og nemendur í stjúpfjölskyldum $(\mathrm{p}<0,001)$. Ekki var marktækt samband milli fjölda hreyfidaga í viku og búsetu. Eta-stuðullinn sýnir að fjöldi daga í líkamlegri hreyfingu tengdist mest efnahag foreldra, pó einnig hafi verið nokkur fylgni við fjölskyldugerð, bekkjardeild og uppruna foreldra, en minnst var fylgnin við kynferði. 
Tafla 2. Líkamleg hreyfing í einstökum hópum íslenskra grunnskólanema.

\begin{tabular}{|c|c|c|c|c|c|c|c|c|}
\hline & \multicolumn{4}{|c|}{ Ráðlögð líkamleg hreyfing } & \multicolumn{4}{|c|}{ Vikudagar í líkamlegri hreyfingu } \\
\hline & $\%$ & $\mathrm{n}$ & $\mathrm{p}^{1}$ & $\begin{array}{c}\text { Phi/ } \\
\text { Cramér's V }{ }^{2}\end{array}$ & $\begin{array}{c}\text { Meðal- } \\
\text { tal }\end{array}$ & $\begin{array}{l}\text { Staðal- } \\
\text { frávik }\end{array}$ & $\mathrm{p}^{1}$ & $\mathrm{Eta}^{2}$ \\
\hline \multicolumn{9}{|l|}{ Kynferði } \\
\hline Piltur & 25,0 & $734 / 2937$ & & & 4,67 & 2,03 & & \\
\hline Stúlka & 17,0 & $516 / 3043$ & 0,000 & 0,099 & 4,41 & 1,94 & 0,000 & 0,066 \\
\hline \multicolumn{9}{|l|}{ Bekkur } \\
\hline 6. bekkur & 23,5 & $441 / 1878$ & & & 4,85 & 1,82 & & \\
\hline 8. bekkur & 19,6 & $429 / 2184$ & 0,006 & 0,041 & 4,54 & 1,93 & 0,000 & 0,124 \\
\hline 10. bekkur & 20,1 & $404 / 2010$ & & & 4,23 & 2,19 & & \\
\hline
\end{tabular}

\section{Uppruni foreldra}

Báđir af íslenskum uppruna

$\begin{array}{llllllll}21,6 & 1066 / 4941 & & & 4,63 & 1,96 & & \\ 18,3 & 121 / 663 & 0,036 & 0,033 & 4,21 & 2,05 & 0,000 & 0,113 \\ 17,6 & 68 / 386 & & & 3,83 & 2,20 & & \end{array}$

\section{Fjölskyldugerð}

Báðir kynforeldrar

$4,69 \quad 1,92$

Einstætt foreldri

$15,8 \quad 108 / 683$

$4,02 \quad 2,13$

Stjúpforeldri

$17,6 \quad 70 / 398$

0,000

0,058

4,11

2,13

$0,000 \quad 0,135$

Önnur fjölskyldugerð

$18,8 \quad 108 / 576$

$4,16 \quad 2,14$

Efnahagur fjölskyldu

$$
\begin{aligned}
& \text { Lakur (0-7 stig) } \\
& \text { Miðlungs (8-10 stig) } \\
& \text { Hár (11-13 stig) }
\end{aligned}
$$$$
14,8 \quad 141 / 953
$$$$
18,8 \quad 667 / 3557
$$$$
0,000
$$

0,131

$4,03 \quad 2,04$

$29,9 \quad 433 / 1449$

$4,43 \quad 1,99$

$0,000 \quad 0,174$

\section{Búseta}

Höfuðborgarsvæði

$$
21,4 \quad 764 / 3572
$$

4,54

2,01

Landsbyggð

$$
20,4 \quad 510 / 2500
$$

0,352

0,012

$4,52 \quad 1,98$

$0,620 \quad 0,006$

${ }^{1}$ p-gildi byggja á kí-kvaðrat prófi í tilvikum ráðlagðrar hreyfingar og t- eða F-prófi í tilvikum vikudaga í hreyfingu ( $\mathrm{t}$-prófið ber saman tvo hópa en F-prófið fleiri hópa).

${ }^{2}$ Stuðlarnir Phi og Cramér's V eru reiknaðir út frá krosstöflum. Phi sýnir fylgni milli breyta pegar báðar breytur eru tvígildar og Cramér's V sýnir fylgni pegar önnur eða báðar breyturnar eru marggildar. Stuðullinn Eta sýnir fylgni milli nafnbreytu eða flokkaðrar breytu annars vegar og jafnbilabreytu hins vegar. 


\section{Umræður}

Umtalsverður hluti íslenskra grunnskólanema í 6., 8. og 10. bekk, eða um 79\%, uppfyllir ekki viðmið um ráðlagða daglega hreyfingu. Pá var munur á líkamlegri hreyfingu eftir kyni og bekkjardeild par sem fleiri piltar en stúlkur náðu viðmiðum um daglega hreyfingu og nemendur í 6. bekk náðu frekar viðmiðunum en eldri nemendur. Pá var marktækur munur á líkamlegri hreyfingu skólabarna milli hópa eftir efnahag fjölskyldu, pjóðernisuppruna foreldra og fjölskyldugerð, en ekki eftir búsetu peirra.

Einungis um 21\% ungmenna í rannsókninni uppfyllir alpjóðlegar ráðleggingar um daglega hreyfingu (60 mínútur á dag). Í nýlegri skýrslu um hreyfiráðleggingar fyrir börn og unglinga hafa fundist tengsl milli aukinnar hreyfingar og kjörpyngdar, lægri fitusöfnunar og betri efnaskiptaheilsu (Powell o.fl., 2018). Rannsóknir hafa sýnt að hreyfing sé ákjósanlegur lífstílspáttur sem spornað geti við offitu (Laurson o.fl., 2015). Niðurstöður rannsóknarinnar styðja ákall um aðgerðir til að auka hreyfingu meðal barna og unglinga. Sérstaklega parf að huga að aukinni hreyfingu stúlkna par sem einungis $17 \%$ peirra uppfylla ráðleggingar um daglega líkamlega hreyfingu samanborið við 25\% drengja, en pessar niðurstöður eru í samræmi við eldri íslenska rannsókn (Kristján Pór Magnússon o.fl., 2011). Erlendar rannsóknir styðja einnig niðurstöðurnar. Grao-Cruces og félagar skoðuðu í nýlegri yfirlitsgrein 29 rannsóknir par sem viðfangsefnið var hreyfing grunnskólanema á skólatíma. Par kom fram að minna en 25\% grunnskólanema náðu 30 mínútum af miðlungs eða mikilli hreyfingu daglega. Einnig eru erlendu niðurstöðurnar í samræmi við okkar niðurstöður varðandi kynjamuninn (Grao-Cruces o.fl., 2020). Mikilvægt er að standa vörð um pann tíma sem börn og ungmenni fá til hreyfingar innan grunn- og framhaldsskóla, par sem fjöldi og lengd pessara tíma hefur áhrif á hreyfingu af miðlungs- eða mikilli ákefð, pá sérstaklega meðal unglinga (Sprengeler o.fl., 2019).

Fleiri nemendur í 6. bekk uppfylltu viðmið um 60 mínútna hreyfingu en nemendur í 8. og 10. bekk. Hins vegar voru færri stúlkur sem náðu viðmiðunum í 8. bekk en bæði stúlkur í 6. og 10. bekk. Niðurstöðurnar eru í samræmi við erlendar rannsóknir en samkvæmt peim dregur mest úr hreyfingu stúlkna á aldursbilinu 9-12 ára en 13-16 ára hjá drengjum par sem talið er að kynproski hafi áhrif á pessar breytingar og stúlkur proskist að meðaltali fyrr, sem að hluta til geti útskýrt pennan kynjamun (Dumith o.fl., 2011). Í evrópskri rannsókn frá árinu 2013 kom í ljós að verulega dró úr hreyfingu af miðlungs eða mikilli ákefð frá aldrinum 9 til 15 ára og meira hjá drengjum en stúlkum (Ortega o.fl., 2013). Velta má fyrir sér hvort ástæður minnkandi hreyfingar með hækkuðum aldri unglinga gætu tengst peim sálrænu og líkamlegu breytingum sem verða á kynproskaskeiðinu. Einnig fjölgar frístunda- og afpreyingarmöguleikum með hækkandi aldri sem geta dregið úr ípróttapátttöku og hreyfingu.

Um 83\% skólabarna stunda 60 mínútna daglega hreyfingu að minnsta kosti prisvar sinnum í viku og um 71\% peirra að minnsta kosti 4 sinnum í viku. Rannsóknir hafa bent á að pjálfun fjórum sinnum í viku geti haft góð áhrif á heilsuna. Í íslenskri rannsókn á 15-16 ára unglingum kemur fram að peir sem taka pátt í skipulögðum ípróttum, að minnsta kosti 4 sinnum í viku, mælast með meiri heildarhreyfingu, betri líkamshreysti (VO2 max), lægri fituprósentu, styttri skjátíma (Elvar S. Sævarsson o.fl., 2021) og betri námsárangur (Elvar S. Sævarsson o.fl., 2017) en peir sem stunda ípróttir sjaldnar. Ljóst er að ípróttapátttaka hefur áhrif á heildarhreyfingu og heilsuhegðun og pví tilefni til að leita leiða til að unglingar hafi sem jöfnust tækifæri til pátttöku í ípróttum.

Niðurstöður rannsóknarinnar sýna að pátttaka unglinga ílíkamlegri hreyfingu er háð efnahagsstöðu foreldra. Unglingar frá efnaminni fjölskyldum tóku síður pátt í hreyfingu en jafnaldrar frá efnameiri fjölskyldum. Par sem pekkt er að hreyfing á unglingsaldri hefur forspárgildi fyrir hreyfingu síðar á lífsleiðinni (Belanger o.fl., 2015; Telama o.fl., 2005) geta pessar niðurstöður hugsanlega spáð fyrir um heilsufar á fullorðinsárum. Rannsóknir hafa sýnt að lök efnahagsleg staða fjölskyldna hefur áhrif snemma á lífsleiðinni og varir fram á fullorðinsár með tengsl við slæma líkamlega heilsu (Matthews og Gallo, 2011). Leggja parf áherslu á jöfn tækifæri til hreyfingar meðal barna og unglinga óháð fjárhagslegri stöðu fjölskyldna. Frá árinu 2007 hafa sveitarfélög á Íslandi leitast við að jafna tækifæri 
barna og unglinga, 6-18 ára, til pátttöku í íprótta- og tómstundastarfi í formi frístundakorts sem er niðurgreiðsla á pátttökugjöldum. Prátt fyrir pessa aðgerð, pað er innleiðingu frístundakorts, sýna niðurstöður rannsóknarinnar að enn er mikill munur á hreyfingu unglinga frá efnaminni fjölskyldum borið saman við unglinga sem búa við betri efnahag. Frekari rannsókna er pörf til að kanna ástæður pess að unglingar frá efnaminni heimilum hreyfa sig minna.

Skólaípróttir eru mikilvægt framlag til að jafna tækifæri barna og unglinga til hreyfingar. Samkvæmt aðalnámskrá grunnskóla er gert ráð fyrir skólaípróttum að jafnaði prisvar sinnum í viku (Mennta- og menningarmálaráðuneyti, 2013). Niðurstöður rannsóknarinnar sýndu að 79\% pátttakenda stunduðu hreyfingu prisvar sinnum í viku eða oftar. Ein leið til að fjölga peim unglingum sem hreyfa sig oftar í viku væri að fjölga ípróttatímum og hreyfistundum á skólatíma. Í nýlegri alpjóðlegri skýrslu um hreyfingu skólabarna kemur fram að skólinn sé mikilvægur páttur í hreyfingu ungs fólks vegna pess hve löngum tíma dags nemendur verja innan veggja hans. Pví er æskilegt að allir nemendur uppfylli ráłleggingar um líkamlega daglega hreyfingu (60 mínútur á dag) á skólatíma (World Health Organization, 2018). Íslensk rannsókn sýndi fram á mikilvægi skólaíprótta til að auka hreyfingu barna- og unglinga og til að draga úr muni á tíðni hreyfingar milli einstakra hópa (Guðrún Kristjánsdóttir og Rúnar Vilhjálmsson, 2001). Sýnt hefur verið fram á að skólaípróttir hafi jákvæð áhrif á hreyfingu barna og unglinga utan skóla, par sem kennsla í ípróttagreinum og fræðsla um gildi íprótta og hreyfingar getur haft áhrif á viðhorf peirra til hreyfingar (Rúnar Vilhjálmsson og Pórólfur Pórlindsson, 1998).

Pátttaka barna og unglinga í skipulögðum ípróttum hefur jákvæð áhrif á félagslega aðlögun og eykur félagslegt tengslanet (Kjonniksen o.fl., 2009; Nielsen o.fl., 2013; Yu o.fl., 2015). Niðurstöður okkar gefa til kynna að unglingar af erlendum uppruna stundi síður líkamlega hreyfingu, sem er í takt við erlendar rannsóknir (Mahmood o.fl., 2019). Nýta parf pátttöku barna og unglinga í skipulögðu ípróttastarfi sem vettvang til tengslamyndunar og virkrar pátttöku í samfélaginu með sérstaka áherslu á pátttakendur af erlendum uppruna. Jafnframt parf að auðvelda foreldrum peirra að tengjast sjálfboðaliðastarfi ípróttafélaganna par sem sýnt hefur verið fram á að hvatning foreldra til ípróttapátttöku er áhrifavaldur á ípróttapátttöku ungmenna (Viðar Halldórsson, 2014).

Rannsóknir á hreyfingu barna og ungmenna eftir búsetu hafa sýnt að ungmenni í dreifbýli hreyfi sig minna en ungmenni í péttbýli (Felton o.fl., 1998; Guðrún Kristjánsdóttir og Rúnar Vilhjálmsson, 2001; Kristján Pór Magnússon o.fl., 2011), pó aðrar rannsóknir hafi pó bent til hins gagnstæða (Liu o.fl., 2008) og að unglingar búsettir í dreifbýli hafi betra pol (Machado-Rodrigues o.fl., 2014). Petta misræmi í erlendum rannsóknum gæti skýrst af mismunandi skilgreiningum á péttbýli og dreifbýli. Niðurstöður rannsóknar okkar sýndu ekki mun á hreyfingu grunnskólanema eftir búsetu. Hugsanleg skýring gæti verið að sveitarfélög í dreifbýli og péttbýli á Îslandi bjóði grunnskólanemum sínum upp á sambærileg tækifæri til hreyfingar í skólaípróttum, á skólalóðum og í nærumhverfinu. Sýnt hefur verð fram á að aðstaða hefur áhrif á hreyfingu og að pættir eins og græn svæði og aðgengileg utan- og innanhúss ípróttaaðstaða styðja við hreyfingu (Kajosaari og Laatikainen, 2020). Par sem rannsóknin leiddi í ljós að einungis um $21 \%$ barna og unglinga náði daglegri ráðlegri hreyfingu purfa sveitarfélög um allt land að huga að uppbyggingu hreyfimenningar með hreyfiörvandi umhverfisvænni aðstöðu til að örva börn og unglinga til aukinnar hreyfingar.

\section{Styrkleikar og takmarkanir}

Styrkleikar pessarar rannsóknar eru að hún byggir á landsúrtaki með háu svarhlutfalli og notkun staðlaðra spurningalista. Meðal takmarkana má nefna að hreyfing var einungis metin með útfylltum spurningalista, en ekki með hreyfimælum sem hefðu getað gefið frekari upplýsingar. Ýmsir bakgrunnspættir nemenda voru ekki teknir til skoðunar, svo sem menntun og starfsstétt foreldra. Pá má nefna að hreyfing var ekki metin með tilliti til fötlunar eða annarra heilsufarspátta sem hefðu getað tengst umfangi hreyfingar. 


\begin{abstract}
Ályktun
Niðurstöður leiða í ljós ónóga hreyfingu nemenda í 6., 8. og 10. bekk grunnskóla. Yngri nemendur hreyfa sig meira en eldri nemendur og piltar hreyfa sig meira en stúlkur. Nemendur af innlendum uppruna stunda oftar ráðlagða hreyfingu en nemendur af erlendum uppruna. Nemendur sem búa hjá báðum kynforeldrum hreyfa sig meira en nemendur í öðrum fjölskyldugerðum. Algengara er að nemendur úr vel stæðum fjölskyldum nái viðmiðum um ráðlagða hreyfingu en nemendur sem búa við lakari efnahag. Vinna parf að hreyfieflingu grunnskólanema með fræðslu um gildi hennar, daglegum hreyfistundum á skólatíma og markvissum ípróttatímum. Jafna parf pátttökumöguleika barna í ípróttum utan skólans með aðkomu sveitarfélaganna. Fjölga parf möguleikum til hreyfingar fyrir alla utan húss sem innan í sveitarfélögum landsins.
\end{abstract}

\title{
Physical activity among Icelandic adolescents HBSC
}

The value of physical activity for physical and mental health is well known. Despite this knowledge, exercise decreases from childhood to adolescence and, in general, exercise is deficient. It is, therefore, important to study the physical activity of children and adolescents with the intention of promoting it and combating inactivity.

The aim of this study was to examine the extent of physical activity of Icelandic compulsory school students in 6th, 8th, and 10th grade and its relationship to gender, age, national origin, family structure, economic status, and place of residence, as well as examining the proportion of students who achieve 60 minutes of recommended physical activity daily.

Data was derived from the national survey Health Behavior in School-aged Children (HBSC) conducted in 2018. Participants in the study were 6,102 students in 6th, 8th and 10th grade in the country's compulsory schools. Questionnaires were administered to students asking about the number of days per week that participants engaged in "physical activity for a total of 60 minutes or more per day". Students also answered questions about their sex and school grade, the economic status of the family, the national origin of their parents, their family structure, and place of residence.

On average, the students engaged in physical activity for 4.5 days a week and the proportion of students who reached the recommended daily physical activity was only $21.0 \%$. More boys than girls achieved recommended physical activity and more students in 6th grade achieved recommended physical activity than older students. Students who came from families of lower economic status, other family structure than living with both biological parents, and who had parents of foreign origin reached recommended physical activity less often than their counterparts. There was no difference in physical activity between students living in rural and urban areas.

Physical education within schools is a meaningful and purposeful part of a student's education. Lack of physical activity among children and adolescents calls for increased physical activity during school hours. For physical education teachers there is an opportunity to emphasize the core values of physical activity, exercise, and sports participation for both physical, mental, and social well-being. Participation of children and adolescents within sport clubs needs to be more equal, with involvement of the municipalities, highlighting physical activity for everyone both in rural and urban areas.

Key words: Physical activity, sport participation, adolescents, socioeconomic status, family structure, rural/urban 


\section{Um höfunda}

Pórdís Lilja Gísladóttir (thg@hi.is) er dósent í íprótta- og heilsufræði við Menntavísindasvið Háskóla Íslands. Hún lauk B.Sc.-gráðu í íprótta- og heilsufræði frá University of Alabama árið 1985, MA-gráðu 2007 og PhD-gráðu árið 2015 frá Norwegian University of Science \& Technology (NTNU). Rannsóknir hennar eru á sviði heilsu og líðanar ungmenna, hreyfifærni og gildi íprótta og hreyfingar fyrir börn og unglinga.

Rúnar Vilhjálmsson (runarv@hi.is) er prófessor í félagsfræði við Hjúkrunarfræðideild Háskóla Î́lands og er jafnframt gestaprófessor við heilbrigðisvísindadeild Háskólans í Lundi, Svípjóð. Hann lauk BA-prófi í félagsfræði frá Háskóla Íslands árið 1982, meistaraprófi í félagsfræði frá Wisconsinháskóla í Madison árið 1984 og doktorsprófi í félagsfræði frá sama skóla árið 1993. Rannsóknir hans hafa meðal annars beinst að hollustu- og áhættuhegðun ungmenna, félagslegum stuðningi ungmenna og fullorðinna, geðheilsu fullorðinna og heilbrigðispjónustunotkun ásamt aðgengi að heilbrigðispjónustu.

Vaka Rögnvaldsdóttir (vakar@hi.is) er lektor í íprótta- og heilsufræði við Menntavísindasvið Háskóla Î́slands. Hún lauk ípróttakennaraprófi frá Kennaraháskóla Íslands árið 1999, B.Sc.-gráðu í hagfræði frá Auburn University Montgomery árið 2002, M.Sc.-gráðu árið 2011 og PhD-gráðu árið 2020 í íprótta- og heilsufræði frá Háskóla Íslands. Síðastliðin ár hafa rannsóknir hennar aðallega beinst að svefni, hreyfingu og heilsu ungmenna.

\section{About the authors}

Pórdís Lilja Gísladóttir (thg@hi.is) is an associate professor in sports and health sciences at the University of Iceland, School of Education. She completed her B.Sc. degree in sports and health sciences from University of Alabama in 1985, an MA degree in 2007 and a PhD degree in 2015 from the Norwegian University of Science \& Technology (NTNU). Her research focuses are on the health and well-being of young people, motor competence, and the value of sports and exercise for children and adolescents.

Rúnar Vilhjálmsson (runarv@hi.is) is professor of sociology at the University of Iceland Faculty of Nursing, and guest professor in the Department of Health Sciences at the University of Lund, Sweden. He received his B.A. degree in sociology from the University of Iceland in 1982, an M.Sc. degree in sociology from the University of Wisconsin-Madison in 1984, and a PhD degree in sociology from UW-Madison in 1993. His research focuses on positive and negative health-related behavior in adolescents, social support in adolescence and adulthood, adult mental health, use of health services and access to health care.

Vaka Rögnvaldsdóttir (vakar@hi.is) is an assistant professor in sports and health sciences at the University of Iceland, School of Education. She completed a physical education teacher's degree from the Icelandic School of Education in 1999, a B.Sc. degree in economics from Auburn University Montgomery in 2002, an M.Sc. degree in 2011 and a PhD degree in 2020 from the Faculty of Health Promotion, Sport and Leisure Studies at the University of Iceland. Recently, her research has focused on sleep, physical activity and health of adolescents. 


\section{Heimildir}

Aarnio, M., Winter, T., Kujala, U. og Kaprio, J. (2002). Associations of health related behaviour, social relationships, and health status with persistent physical activity and inactivity: A study of Finnish adolescent twins. British Journal of Sports Medicine, 36(5), 360-364. https://doi.org/10.1136/ bjsm.36.5.360

Aaron, D. J., Kriska, A. M., Dearwater, S. R., Anderson, R. L., Olsen, T. L., Cauley, J. A. og Laporte, R. E. (1993). The epidemiology of leisure physical activity in an adolescent population. Medicine \& Science in Sports \& Exercise, 25(7), 847-853. https://doi.org/10.1249/00005768-199307000-00014

Adler, N. E., Boyce, T., Chesney, M. A., Cohen, S., Folkman, S., Kahn, R. L. og Syme, S. L. (1994). Socioeconomic status and health. The challenge of the gradient. American Psychologist, 49(1), 15-24. https://doi.org/10.1037//0003-066x.49.1.15

Amalía Björnsdóttir, Baldur Kristjánsson og Börkur Hansen. (2009). Tíminn eftir skólann skiptir líka máli. Netla - Veftimarit um uppeldi og menntun. http://hdl.handle.net/1946/13983

Andersen, R. E., Crespo, C. J., Bartlett, S. J., Cheskin, L. J. og Pratt, M. (1998). Relationship of physical activity and television watching with body weight and level of fatness among children: Results from the Third national health and nutrition examination survey. JAMA, 279(12), 938-942. https://doi.org/10.1001/jama.279.12.938

Babey, S. H., Wolstein, J. og Diamant, A. L. (2018). Few California children and adolescents meet physical activity guidelines. Policy Brief UCLA Center for Health Policy Research, 2018(8), 1-8. https:// www.ncbi.nlm.nih.gov/pubmed/30311767

Bedard, C., Hanna, S. og Cairney, J. (2020). A longitudinal study of sport participation and perceived social competence in youth. Journal of Adolescent Health, 66(3), 352-359. https://doi.org/10.1016/j. jadohealth.2019.09.017

Belanger, M., Sabiston, C. M., Barnett, T. A., O'Loughlin, E., Ward, S., Contreras, G. og O'Loughlin, J. (2015). Number of years of participation in some, but not all, types of physical activity during adolescence predicts level of physical activity in adulthood: Results from a 13-year study. International Journal of Behavioral Nutrition and Physical Activity, 12, 76. https://doi.org/10.1186/ s12966-015-0237-x

Bell, S. L., Audrey, S., Gunnell, D., Cooper, A. og Campbell, R. (2019). The relationship between physical activity, mental wellbeing and symptoms of mental health disorder in adolescents: A cohort study. International Journal of Behavioral Nutrition and Physical Activity, 16(1), 138. https://doi. org/10.1186/s12966-019-0901-7

Biro, F. M. og Wien, M. (2010). Childhood obesity and adult morbidities. The American Journal of Clinical Nutrition, 91(5), 1499S-1505S. https://doi.org/10.3945/ajcn.2010.28701B

Chzhen, Y., Moor, I., Pickett, W., Toczydlowska, E. og Stevens, G. (2016). Family affluence and inequality in adolescent health and life satisfaction: Evidence from the HBSC study 2002-2014. UNICEF Innocenti Research Centre.

Clemens, S. L. og Lincoln, D. J. (2018). Where children play most: Physical activity levels of school children across four settings and policy implications. Australian and New Zealand Journal of Public Health, 42(6), 575-581. https://doi.org/10.1111/1753-6405.12833

Currie, C., Zanotti, C., Morgan, A., Currie, D., de Looze, M., Roberts, C., Samdal, O., Smith, O. R. F. og Barnekow, V. (ritstjórar). (2012). Social determinants of health and well-being among young people. Health behaviour in school-aged children (HBSC) study: International report from the 2009/2010 survey. WHO. https://www.euro.who.int/_data/assets/pdf_file/0003/163857/Social-determinants-of-health-and-well-being-among-young-people.pdf 
Dollman, J. og Lewis, N. R. (2010). The impact of socioeconomic position on sport participation among South Australian youth. Journal of Science and Medicine in Sport, 13(3), 318-322. https://doi. org/10.1016/j.jsams.2009.04.007

Dumith, S. C., Gigante, D. P., Domingues, M. R. og Kohl, H. W., 3rd. (2011). Physical activity change during adolescence: A systematic review and a pooled analysis. International Journal of Epidemiology, 40(3), 685-698. https://doi.org/10.1093/ije/dyq272

Einar B. Porsteinsson og Ársæll Arnarsson. (2018). Heilsa og lifskjör skólanema á Íslandi. Menntavísindastofnun; Menntavísindasvið; Háskóli Î́slands. https:/www.stjornarradid.is/library/01--Frettatengt---myndir-og-skrar/MRN/HBSC_Sk\%C3\%BDrsla\%202018_Landssv\%C3\%A6\%C3\%B0i. pdf

Elgar, F. J., Pfortner, T. K., Moor, I., de Clercq, B., Stevens, G. W. og Currie, C. (2015). Socioeconomic inequalities in adolescent health 2002-2010: A time-series analysis of 34 countries participating in the Health behaviour in school-aged children study. The Lancet, 385(9982), 2088-2095. https://doi. org/10.1016/S0140-6736(14)61460-4

Elvar S. Sævarsson, Erla Svansdóttir, Pórarinn Sveinsson, Tinna L. Ásgeirsdóttir, Sigurbjörn Á. Arngrímsson og Erlingur Jóhannsson. (2017). Organized leisure-time sport participation and academic achievement in preadolescents. Scandinavian Journal of Public Health, 45(8), 861-868. https://doi. org/10.1177/1403494817705560

Elvar S. Sævarsson, Vaka Rögnvaldsdóttir, Rúna Stefánsdóttir og Erlingur Jóhannsson. (2021). Organized sport participation, physical activity, sleep and screen time in 16-year-old adolescents. International Journal of Environmental Research and Public Health, 18(6), 3162. https://doi. org/10.3390/ijerph18063162

Farooq, A., Martin, A., Janssen, X., Wilson, M. G., Gibson, A. M., Hughes, A. og Reilly, J. J. (2020). Longitudinal changes in moderate-to-vigorous-intensity physical activity in children and adolescents: A systematic review and meta-analysis. Obesity Reviews, 21(1), e12953. https://doi. org/10.1111/obr.12953

Fedewa, A. L. og Ahn, S. (2011). The effects of physical activity and physical fitness on children's achievement and cognitive outcomes: A meta-analysis. Research Quarterly for Exercise and Sport, 82(3), 521-535. https://doi.org/10.1080/02701367.2011.10599785

Felton, G. M., Pate, R. R., Parsons, M. A., Ward, D. S., Saunders, R. P., Trost, S. og Dowda, M. (1998). Health risk behaviors of rural sixth graders. Research in Nursing \& Health, 21(6), 475-485. https://doi.org/10.1002/(sici)1098-240x(199812)21:6<475::aid-nur2>3.0.co;2-q

Fox, C. K., Barr-Anderson, D., Neumark-Sztainer, D. og Wall, M. (2010). Physical activity and sports team participation: Associations with academic outcomes in middle school and high school students. Journal of School Health, 80(1), 31-37. https://doi.org/10.1111/j.1746-1561.2009.00454.x

Freedman, D. S., Mei, Z., Srinivasan, S. R., Berenson, G. S. og Dietz, W. H. (2007). Cardiovascular risk factors and excess adiposity among overweight children and adolescents: The Bogalusa heart study. The Journal of Pediatrics, 150(1), 12-17. https://doi.org/10.1016/j.jpeds.2006.08.042

Grao-Cruces, A., Velasquez-Romero, M. J. og Rodriguez-Rodriguez, F. (2020). Levels of physical activity during school hours in children and adolescents: A systematic review. International Journal of Environmental Research and Public Health, 17(13), 4773. https://doi.org/10.3390/ijerph17134773

Guðrún Kristjánsdottir og Rúnar Vilhjálmsson. (2001). Sociodemographic differences in patterns of sedentary and physically active behavior in older children and adolescents. Acta Paediatrica, 90(4), 429-435. https://www.ncbi.nlm.nih.gov/pubmed/11332936 
Guðrún Sunna Gestsdóttir. (2016). Mental well-being in adolescence and young adulthood. Changes and association with fitness and physical activity [doktorsritgerð, Háskóli Íslands]. Skemman. http:// hdl.handle.net/1946/24768

Hallal, P. C., Victora, C. G., Azevedo, M. R. og Wells, J. C. (2006). Adolescent physical activity and health: A systematic review. Sports Medicine, 36(12), 1019-1030. https://doi.org/10.2165/00007256200636120-00003

Hatch, L. M., Williams, R. A., Dring, K. J., Sunderland, C., Nevill, M. E. og Cooper, S. B. (2021). Activity patterns of primary school children during participation in The daily mile. Scientific Reports, 11(1), 7462. https://doi.org/10.1038/s41598-021-86631-2

Hebert, J. J., Moller, N. C., Andersen, L. B. og Wedderkopp, N. (2015). Organized sport participation is associated with higher levels of overall health-related physical activity in children (CHAMPS Study-DK). PLoS One, 10(8), e0134621. https://doi.org/10.1371/journal.pone.0134621

Inchley, J. C., Currie, D. B., Todd, J. M., Akhtar, P. C. og Currie, C. E. (2005). Persistent sociodemographic differences in physical activity among Scottish schoolchildren 1990-2002. European Journal of Public Health, 15(4), 386-388. https://doi.org/10.1093/eurpub/cki084

Kajosaari, A. og Laatikainen, T. E. (2020). Adults' leisure-time physical activity and the neighborhood built environment: A contextual perspective. International Journal of Health Geographics, 19(1), 35. https://doi.org/10.1186/s12942-020-00227-z

Kjonniksen, L., Anderssen, N. og Wold, B. (2009). Organized youth sport as a predictor of physical activity in adulthood. Scandinavian Journal of Medicine \& Science in Sports, 19(5), 646-654. https:// doi.org/10.1111/j.1600-0838.2008.00850.x

Kokko, S., Martin, L., Geidne, S., Van Hoye, A., Lane, A., Meganck, J., Scheerder, J., Seghers, J., Villberg, J., Kudlacek, M., Badura, P., Mononen, K., Blomqvist, M., de Clercq, B. og Koski, P. (2019). Does sports club participation contribute to physical activity among children and adolescents? A comparison across six European countries. Scandinavian Journal of Public Health, 47(8), 851-858. https://doi.org/10.1177/1403494818786110

Kristján Pór Magnússon, Sigurbjörn Árni Arngrímsson, Pórarinn Sveinsson og Erlingur Jóhannsson. (2011). Líkamshreyfing 9 og 15 ára íslenskra barna í ljósi lýðheilsumarkmiða. Laknablaðið, 97(2), 75-81. http://www.laeknabladid.is/tolublod/2011/02/nr/4118

Lang, C., Kalak, N., Brand, S., Holsboer-Trachsler, E., Puhse, U. og Gerber, M. (2016). The relationship between physical activity and sleep from mid adolescence to early adulthood. A systematic review of methodological approaches and meta-analysis. Sleep Medicine Reviews, 28, 32-45. https:// doi.org/10.1016/j.smrv.2015.07.004

Langoy, A., Smith, O. R. F., Wold, B., Samdal, O. og Haug, E. M. (2019). Associations between family structure and young people's physical activity and screen time behaviors. BMC Public Health, 19(1), 433. https://doi.org/10.1186/s12889-019-6740-2

Laurson, K. R., Lee, J. A. og Eisenmann, J. C. (2015). The cumulative impact of physical activity, sleep duration, and television time on adolescent obesity: 2011 Youth risk behavior survey. Journal of Physical Activity and Health, 12(3), 355-360. https://doi.org/10.1123/jpah.2013-0402

Lipnowski, S., LeBlanc, C. M. A., Canadian Paediatric Society, Healty Active Living og Sports Medicine Committee. (2012). Healthy active living: Physical activity guidelines for children and adolescents. Paediatrics \& Child Health, 17(4), 209-210. https://doi.org/10.1093/pch/17.4.209 
Lipsky, L. M., Nansel, T. R., Haynie, D. L., Liu, D., Li, K., Pratt, C. A., Iannotti, R. J., Dempster, K. W. og Simons-Morton, B. (2017). Diet quality of US adolescents during the transition to adulthood: Changes and predictors. The American Journal of Clinical Nutrition, 105(6), 1424-1432. https://doi. org/10.3945/ajcn.116.150029

Liu, J., Bennett, K. J., Harun, N. og Probst, J. C. (2008). Urban-rural differences in overweight status and physical inactivity among US children aged 10-17 years. The Journal of Rural Health, 24(4), 407-415. https://doi.org/10.1111/j.1748-0361.2008.00188.x

Lýðheilsustöð. (2008). Ráðleggingar um hreyfingu. https://www.landlaeknir.is/servlet/file/store93/ item11179/NM30399_hreyfiradleggingar_baeklingur_lores_net.pdf

Machado-Rodrigues, A. M., Coelho-E-Silva, M. J., Mota, J., Padez, C., Martins, R. A., Cumming, S. P., Riddoch, C. og Malina, R. M. (2014). Urban-rural contrasts in fitness, physical activity, and sedentary behaviour in adolescents. Health Promotion International, 29(1), 118-129. https://doi. org/10.1093/heapro/das054

Mahmood, B., Bhatti, J. A., Leon, A. og Gotay, C. (2019). Leisure time physical activity levels in immigrants by ethnicity and time since immigration to Canada: Findings from the 2011-2012 Canadian community health survey. Journal of Immigrant and Minority Health, 21(4), 801-810. https://doi.org/10.1007/s10903-018-0789-3

Manios, Y., Kafatos, A. og Codrington, C. (1999). Gender differences in physical activity and physical fitness in young children in Crete. The Journal of Sports Medicine and Physical Fitness, 39(1), 24-30. https://www.ncbi.nlm.nih.gov/pubmed/10230165

Marques, A., Ekelund, U. og Sardinha, L. B. (2016). Associations between organized sports participation and objectively measured physical activity, sedentary time and weight status in youth. Journal of Science and Medicine in Sport, 19(2), 154-157. https://doi.org/10.1016/j.jsams.2015.02.007

Matthews, K. A. og Gallo, L. C. (2011). Psychological perspectives on pathways linking socioeconomic status and physical health. Annual Review of Psychology, 62, 501-530. https://doi.org/10.1146/ annurev.psych.031809.130711

Mennta- og menningarmálaráðuneyti. (2013). Aðalnámskrá grunnskóla: Almennur hluti: Greinasvið 2013.

Myers, J., Kokkinos, P. og Nyelin, E. (2019). Physical activity, cardiorespiratory fitness, and the metabolic syndrome. Nutrients, 11(7), 1652. https://doi.org/10.3390/nu11071652

Nielsen, G., Hermansen, B., Bugge, A., Dencker, M. og Andersen, L. B. (2013). Daily physical activity and sports participation among children from ethnic minorities in Denmark. European Journal of Sport Science, 13(3), 321-331. https://doi.org/10.1080/17461391.2011.635697

OECD. (2017). Obesity update 2017. http://www.oecd.org/health/health-systems/ObesityUpdate-2017.pdf

Ortega, F. B., Konstabel, K., Pasquali, E., Ruiz, J. R., Hurtig-Wennlöf, A., Mäestu, J., Löf, M., Harro, J., Bellocco, R., Labayen, I., Veidebaum, T. og Sjöstrom, M. (2013). Objectively measured physical activity and sedentary time during childhood, adolescence and young adulthood: A cohort study. PLoS One, 8(4), e60871. https://doi.org/10.1371/journal.pone.0060871

Pedersen, S. og Seidman, E. (2005). Contexts and correlates of out-of-school activity participation among low-income urban adolescents. Í J. L. Mahoney, R. W. Larson og J. S. Eccles (ritstjórar), Organized activities as contexts of development: Extracurricular activities, after-school and community programs (bls. 85-109). Erlbaum. 
Powell, K. E., King, A. C., Buchner, D. M., Campbell, W. W., DiPietro, L., Erickson, K. I., Hillman, C. H., Jakicic, J. M., Janz, K. F., Katzmarzyk, P. T., Kraus, W. E., Macko, R. F., Marquez, D. X., McTiernan, A., Pate, R. R., Pescatello, L. S. og Whitt-Glover, M. C. (2018). The scientific foundation for the Physical activity guidelines for Americans, 2nd edition. Journal of Physical Activity and Health, 16(1), 1-11. https://doi.org/10.1123/jpah.2018-0618

Pulido Sanchez, S. og Iglesias Gallego, D. (2021). Evidence-based overview of accelerometermeasured physical activity during school recess: An updated systematic review. International Journal of Environmental Research and Public Health, 18(2), 578. https://doi.org/10.3390/ijerph18020578

Riddoch, C. J., Bo Andersen, L., Wedderkopp, N., Harro, M., Klasson-Heggebø, L., Sardinha, L. B., Cooper, A. R. og Ekelund, U. (2004). Physical activity levels and patterns of 9- and 15-yr-old European children. Medicine \& Science in Sports \& Exercise, 36(1), 86-92. https://doi.org/10.1249/01. MSS.0000106174.43932.92

Rúnar Vilhjálmsson og Pórólfur Pórlindsson. (1998). Factors related to physical activity: A study of adolescents. Social Science \& Medicine, 47(5), 665-675. https://doi.org/10.1016/s02779536(98)00143-9

Sallis, J. F. (1993). Epidemiology of physical activity and fitness in children and adolescents. Critical Reviewsin FoodScience andNutrition, 33(4-5), 403-408. https://doi.org/10.1080/10408399309527639

Saunders, T. J. og Vallance, J. K. (2017). Screen time and health indicators among children and youth: Current evidence, limitations and future directions. Applied Health Economics and Health Policy, 15(3), 323-331. https://doi.org/10.1007/s40258-016-0289-3

Singh, G. K., Yu, S. M., Siahpush, M. og Kogan, M. D. (2008). High levels of physical inactivity and sedentary behaviors among US immigrant children and adolescents. Archives of Pediatrics and Adolescent Medicine, 162(8), 756-763. https://doi.org/10.1001/archpedi.162.8.756

Sprengeler, O., Buck, C., Hebestreit, A., Wirsik, N. og Ahrens, W. (2019). Sports contribute to total moderate to vigorous physical activity in school children. Medicine \& Science in Sports \& Exercise, 51(8), 1653-1661. https://doi.org/10.1249/MSS.0000000000001948

Telama, R., Yang, X., Viikari, J., Valimaki, I., Wanne, O. og Raitakari, O. (2005). Physical activity from childhood to adulthood: A 21-year tracking study. American Journal of Preventive Medicine, 28(3), 267-273. https://doi.org/10.1016/j.amepre.2004.12.003

Torsheim, T., Cavallo, F., Levin, K. A., Schnohr, C., Mazur, J., Niclasen, B., Currie, C. og FAS Development Study Group. (2016). Psychometric validation of the revised family affluence scale: A latent variable approach. Child Indicators Research, 9, 771-784. https://doi.org/10.1007/s12187-0159339-x

Toselli, S. og Belcastro, M. G. (2017). Participation in sports, body composition, and fitness characteristics in children according to ethnic background. Scandinavian Journal of Medicine \& Science in Sports, 27(12), 1913-1926. https://doi.org/10.1111/sms.12843

Trudeau, F. og Shephard, R. J. (2009). Relationships of physical activity to brain health and the academic performance of schoolchildren. American Journal of Lifestyle Medicine, 4(2), 138-150. https://doi.org/10.1177/1559827609351133

Vaka Rögnvaldsdóttir, Berglind M. Valdimarsdóttir, Robert J. Brychta, Soffía M. Hrafnkelsdóttir, Sigurbjörn Á. Arngrímsson, Erlingur Jóhannsson, Kong Y. Chen og Sigrîður L. Guðmundsdóttir. (2018). Hreyfing og svefn íslenskra ungmenna. Laknablaðið, 104(2), 79-85. https://doi.org/10.17992/ lbl.2018.02.173 
Van Hecke, L., Loyen, A., Verloigne, M., van der Ploeg, H. P., Lakerveld, J., Brug, J., de Bourdeaudhuij, I., Ekelund, U., Donnelly, A., Hendriksen, I. og Deforche, B. (2016). Variation in population levels of physical activity in European children and adolescents according to cross-European studies: A systematic literature review within DEDIPAC. International Journal of Behavioral Nutrition and Physical Activity, 13, 70. https://doi.org/10.1186/s12966-016-0396-4

Viðar Halldórsson. (2014). Ípróttapátttaka íslenskra ungmenna: Próun ípróttapátttöku og greining á félagslegum áhrifapáttum. Netla - Veftimarit um uppeldi og menntun. https://netla.hi.is/greinar/2014/ ryn/007.pdf

Walters, S., Barr-Anderson, D. J., Wall, M. og Neumark-Sztainer, D. (2009). Does participation in organized sports predict future physical activity for adolescents from diverse economic backgrounds? Journal of Adolescent Health, 44(3), 268-274. https://doi.org/10.1016/j.jadohealth.2008.08.011

World Health Organization. (2010). Global recommendations on physical activity for health. http:// apps.who.int/iris/bitstream/10665/44399/1/9789241599979_eng.pdf

World Health Organization. (2018). Promoting physical activity in the education sector. https://www. euro.who.int/__data/assets/pdf_file/0006/382335/fs-education-eng.pdf

World Health Organization. (2020). Physical activity. https://www.who.int/news-room/fact-sheets/ detail/physical-activity

Yu, S. M., Newport-Berra, M. og Liu, J. (2015). Out-of-school time activity participation among US-immigrant youth. Journal of School Health, 85(5), 281-288. https://doi.org/10.1111/josh.12255

Zaccagni, L., Toselli, S., Celenza, F., Albertini, A. og Gualdi-Russo, E. (2017). Sports activities in preschool children differed between those born to immigrants and native Italians. Acta Paediatrica, 106(7), 1184-1191. https://doi.org/10.1111/apa.13862

Pórólfur Pórlindsson, Rúnar Vilhjálmsson og Gunnar Valgeirsson. (1990). Sport participation and perceived health status: A study of adolescents. Social Science \& Medicine, 31(5), 551-556. https://doi. org/10.1016/0277-9536(90)90090-f

Pórdís Gísladóttir, Rúnar Vilhjálmsson og Vaka Rögnvaldsdóttir. (2021).

Hreyfing íslenskra grunnskólanema.

Netla - Veftímarit um uppeldi og menntun: Sérrit 2021 - HBSC og ESPAD rannsóknirnar

Sótt af http://netla.hi.is/serrit/2021/HBSC_ESPAD_rannsoknir/04.pdf

DOI: https://doi.org/10.24270/serritnetla.2021.8 